\title{
PRODUKSI ENERGI LISTRIK DARI LIMBAH KULIT PISANG (Musa Paradisiaca L.) MENGGUNAKAN TEKNOLOGI MICROBIAL FUEL CELLS DENGAN PERMANGANAT SEBAGAI KATOLIT
}

\author{
LiSA UTAMI $^{1 *}{ }^{*}$ LAZULVA $^{1}$, DAN YUNI FATISA ${ }^{1}$ \\ ${ }^{1}$ Jurusan Pendidikan Kimia, Fakultas Tarbiyah dan Keguruan, UIN Suska Riau, \\ Jalan HR. Soebrantas Panam Km. 15 No. 155 Tuah Madani Tampan Kabupaten Kampar Riau \\ *alamat email korespondensi: lazoelva@uin-suska.ac.id
}

\begin{tabular}{|c|c|}
\hline Informasi Artikel & Abstrak/Abstract \\
\hline $\begin{array}{l}\text { Riwayat Naskah : } \\
\text { Diterima pada } 19 \\
\text { Desember } 2018 \\
\text { Diterima setelah } \\
\text { direvisi pada } 29 \\
\text { Januari } 2019 \\
\text { Diterbitkan pada } 30 \\
\text { Januari } 2019\end{array}$ & $\begin{array}{l}\text { Penelitian ini bertujuan untuk mempelajari bagaimana potensi biomassa yang tidak } \\
\text { termanfaatkan yaitu limbah kulit pisang sebagai sumber energi listrik menggunakan teknologi } \\
\text { Microbial Fuel Cell (MFC). Pengamatan dilakukan terhadap reaktor bejana yang didesain } \\
\text { dengan dua chamber (anoda dan katoda) menggunakan } \mathrm{KMnO}_{4} \text { sebagai katolit dan } \\
\text { dihubungkan dengan rangkaian sel elektrokimia (sel volta) kemudian diukur nilai tegangan, } \\
\text { arus, power density yang dihasilkan dari rangkaian limbah kulit pisang selama } 17 \text { hari. Hasil } \\
\text { pengukuran nilai tegangan maksimum, arus maksimum dan power density maksimum yang } \\
\text { dihasilkan dari reaktor didapatkan berturut-turut sebagai berikut : } 1.455 \text { volt; 0,032 } \\
\text { miliampere; dan } 31,9 \mathrm{~mW} / \mathrm{m}^{2} \text {. Limbah kulit pisang dapat digunakan untuk memproduksi arus } \\
\text { listrik. }\end{array}$ \\
\hline $\begin{array}{l}\text { Keywords: } \\
\text { Microbial Fuel Cells; } \\
\text { Banana peel; } \\
\text { Methilen Blue; } \\
\mathrm{KMnO}_{4}\end{array}$ & $\begin{array}{l}\text { This research aims to study potential of biomass banana peels waste as a source of electrical } \\
\text { energy using microbial fuel cells }(\mathrm{MFC} \text { ). Observations were made on the two chamber vessel } \\
\text { reactors (anodes aand chathodes) using } \mathrm{KMnO}_{4} \text { as catholyte and connected with } \\
\text { electrochemical cell flow (voltaic cells) and then measure the value of voltage, current and } \\
\text { power rdensity from the banana pells waste circuit for } 17 \text { days. The result of measurement of } \\
\text { voltage, current and power density maximum from the reactor respectively are } 1,455 \text { Volt, } \\
0,032 \text { miliampere and } 31,9 \mathrm{~mW} / \mathrm{m}^{2} \text {. Banana peels waste can be used to produce electic } \\
\text { current. }\end{array}$ \\
\hline
\end{tabular}

\section{PENDAHULUAN}

Perubahan iklim yang disebabkan oleh emisi gas rumah kaca dan menipisnya cadangan bahan bakar fosil disertai dengan meningkatnya permintaan dan harga bahan bakar, memaksa umat manusia untuk mengembangkan sumber bahan bakar alternatif yang dapat diperbarui [1]. Microbial Fuel Cell (MFC) merupakan salah satu alternatif teknologi yang mampu menghasilkan energi yang dapat diperbarui tanpa menghasilkan emisi $\mathrm{CO}_{2}$ dan ramah lingkungan. MFC memiliki kemampuan untuk mengubah energi kimia yang tersimpan dalam senyawa organik menjadi energi listrik dengan bantuan mikroorganisme. Bakteri dalam MFC digunakan untuk menghasilkan energi listrik dengan membiodegradasi senyawa organik atau limbah. Hal ini terjadi dengan cara memisahkan bakteri dari oksigen, dan ketika bakteri melepaskan elektron, akan dihasilkan perbedaan potensial antara kedua elektroda yang memproduksi arus listrik [2].
Indonesia termasuk penghasil pisang (Musa Paradisiaca L.) terbesar di Asia dan setiap tahun produksinya terus meningkat, bertambahnya produksi pisang maka semakin banyak pula limbah kulit pisang yang dihasilkan. Limbah kulit pisang ini belum banyak dimanfaatkan, padahal limbah kulit pisang ini mengandung lemak, protein dan karbohidrat yang cukup tinggi. Karbohidrat ini dapat dimanfaatkan sebagai substrat makanan bagi mikroorganisme untuk menghasilkan listrik menggunakan teknologi microbial fuel cells.

Penggunaan limbah dalam sistem MFC mempunyai beberapa keuntungan, seperti kontaminan dalam air limbah dapat menjadi sumber bahan bakar MFC untuk menghasilkan energi listrik sekaligus menurunkan level COD dari limbah [3]. Penelitian menggunakan MFC dengan memanfaatkan limbah telah banyak dilakukan, namun belum ada penelitian MFC dengan memanfaatkan limbah kulit pisang menggunakan $\mathrm{KMnO}_{4}$ sebagai katolit sebagai sumber energi listrik. Penelitian ini bertujuan 
untuk mengetahui produksi energi listrik dari limbah kulit pisang menggunakan teknologi MFC dengan $\mathrm{KMnO}_{4}$ sebagai katolit. Dalam penelitian ini digunakan MFC dengan dua ruang, limbah kulit pisang ditempatkan dalam ruang anoda dan $\mathrm{KMnO}_{4}$ ditempatkan dalam ruang katoda, kemudian diukur nilai tegangan, arus, power density yang dihasilkan dari rangkaian limbah kulit pisang selama 17 hari.

\section{EKSPERIMEN}

Alat, bahan, dan prosedur kerja dalam penelitian ini menggunakan prosedur kerja MFC yang telah peneliti lakukan sebelumnya [4].

\section{Material}

Material yang digunakan pada penelitian ini adalah Membran Nafion 117, grafit, aquadest, $\mathrm{NaOH}, \mathrm{HCl}, \mathrm{H}_{2} \mathrm{O}_{2} 3 \%, \mathrm{H}_{2} \mathrm{SO}_{4} 1 \mathrm{M}, \mathrm{KMnO}_{4} 0,1$ $\mathrm{M}$, metilen blue, buffer fosfat, cling wrap, alumunium foil, limbah kulit pisang.

\section{Instrumentasi}

Instrumentasi yang digunakan pada penelitian ini adalah reaktor MFC tipe dua bejana, mikroamperemeter analog, dan multimeter digital.

\section{Prosedur}

\section{Preparasi Membran Penukar Proton}

Membran Penukar Proton yang digunakan adalah Nafion 117. Perlakuan awal harus dilakukan terhadap membran agar bisa digunakan pada MFC. Membran terlebih dahulu harus direbus dengan aquades selama 1 jam kemudian dididihkan dengan $\mathrm{H}_{2} \mathrm{O}_{2} 3 \%$ selama 1 jam dan dicuci dengan aquadest. Membran selanjutnya didihkan kembali dalam larutan $\mathrm{H}_{2} \mathrm{SO}_{4} 1 \mathrm{M}$ selama 1 jam dan dicuci dengan aquades sebanyak 3 kali. Membran disimpan (direndam) dengan aquades hingga saat akan digunakan. Sebelum mengaplikasikan membran ke dalam reaktor MFC, membran harus dianginkan sampai kering.

\section{Preparasi Elektroda}

Elektroda harus dipersiapkan dengan langkah berikut. Elektroda grafit (karbon aktif) direndam dalam larutan $\mathrm{HCl} 1 \mathrm{M}$ selama 1 hari dan dibilas menggunakan aquades. Kemudian elektroda direndam kembali ke dalam larutan $\mathrm{NaOH} 1 \mathrm{M}$ selama satu hari dan dibilas kembali menggunakan aquades. Elektroda direndam dalam aquades sampai saat akan digunakan.

\section{Preparasi Limbah Kulit Pisang}

Limbah kulit pisang mula-mula dihaluskan dengan blender kemudian disaring dan diambil intisarinya. Sampel kulit pisang yang sudah halus difermentasikan dengan cara dimasukkan ke dalam wadah dan dibungkus rapat dengan kain yang bersih, hal ini bertujuan agar udara tidak dapat masuk ke dalam wadah. Fermentasi dilakukan selama 3 hari.

\section{Eksperimen MFC}

Disiapkan reaktor MFC dengan prinsip dua kompartemen (ruang terpisah), yang terdiri dari bejana anoda dan bejana katoda. Bejana anoda dan katoda dipisahkan dengan menggunakan membran penukar ion yaitu membran Nafion 117. Masingmasing bejana dapat menampung volume $2 \mathrm{~L}$, diantara kedua bejana terdapat lubang dengan diameter 3,5 cm. Di lubang ini dipasang membran penukar proton (Proton Exchange Membran atau disingkat PEM) sebagai tempat transfer proton. Kemudian elektroda grafit (batang karbon batu baterai bekas berukuran A) dipasang di masingmasing ruang dan dihubungkan dengan rangkaian kabel pada alat digital multimeter. Luas permukaan elektroda yang digunakan adalah 1,46 x $10^{-3} \mathrm{~m}^{2}$ dengan diameter 0,3 inci dan panjang 2,25 inci. Kedalam bejana anoda dimasukkan limbah kulit pisang sedangkan ke dalam bejana katoda dimasukkan $\mathrm{KMnO}_{4}$. Larutan $\mathrm{KMnO}_{4}$ dalam penelitian ini berfungsi sebagai akseptor elektron yang berasal dari anoda. Metilen blue juga ditambahkan ke bejana anoda sebagai mediator elektron. Alat MFC terbuat dari kaca dengan ukuran 30 × $21 \times 15 \mathrm{~cm}$.

\section{Pengukuran Kuat Arus dan Tegangan Sistem $M F C$}

Untuk mengukur besarnya energi listrik yang dihasilkan oleh alat MFC pada penelitian ini digunakan digital multimeter Sanwa CD800a untuk mengukur tegangan dan multitester Sunway SW360TRn untuk mengukur kuat arus yang diperoleh. Alat ini kemudian dihubungkan dengan hambatan $5 \Omega$. Sebelum pengukuran dilakukan, multimeter digital dikalibrasi terlebih dahulu. Pengambilan data diambil sesuai dengan variasi waktu. Data berupa kuat arus dan tegangan akan diolah menjadi nilai power density $\left(\mathrm{mW} / \mathrm{m}^{2}\right)$ yaitu daya persatuan luas permukaan elektroda. Power 
density dapat dihitung menggunakan persamaan berikut [5].

$$
\text { Power density }\left(\mathrm{mW} / \mathrm{m}^{2}\right)=\frac{I(\mathrm{~mA}) \times V(\text { Volt })}{A\left(\mathrm{~m}^{2}\right)}
$$

\section{HASIL DAN PEMBAHASAN}

\section{Reaksi Kimia di Bejana Anoda dan Katoda}

Microbial Fuel Cells dalam penelitian ini terdiri dari dua ruang terpisah, ruang anoda dan katoda yang pada masing-masing ruang memiliki elektroda grafit yang diambil dari baterai. Kedua ruang ini dipisahkan oleh membran kation berpori (Proton Exchange Membran Nafion-117), dengan lama waktu operasi 17 hari pada temperatur ruang. Limbah kulit pisang dalam penelitian ini diperoleh dari limbah sisa penggorengan penjual kaki lima di Jl. Uka km 3 Panam Garuda Sakti Pekanbaru Riau. Limbah kulit pisang ditempatkan dalam ruang anoda dibuat dalam kondisi anaerob (bejana tertutup rapat) karena oksigen dalam ruang dapat menghambat arus listrik yang dihasilkan.

Pada kondisi aerob, bakteri menggunakan oksigen sebagai akseptor elektron untuk membentuk air. Namun dalam kondisi anaerob, tidak terdapat oksigen sehingga bakteri harus mengubah akseptor elektronnya menjadi sebuah akseptor insoluble seperti anoda MFC. Mikroba yang berada dalam limbah kulit pisang akan mengoksidasi subrat dalam limbah kulit pisang dan akan menghasilkan elektron dan proton dalam prosesnya. Pada ruang katoda ditempatkan $\mathrm{KMnO}_{4}$ sebagai aseptor elektron. Rangkaian peralatan MFC dalam penelitian ini dapat dilihat pada Gambar 1.

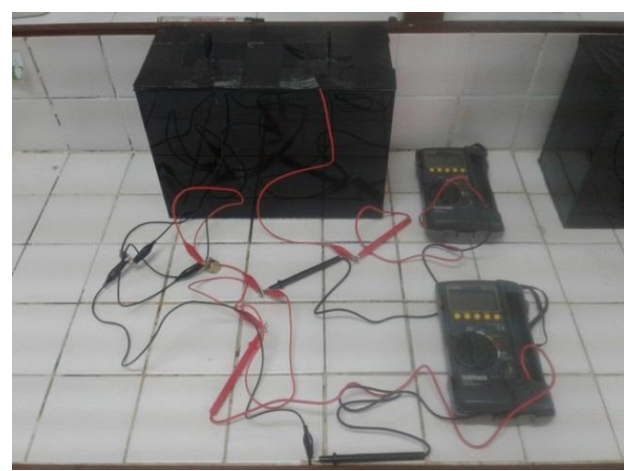

Gambar 1. Rangkaian peralatan MFC Limbah kulit pisang

Energi yang dihasilkan dalam bejana Microbial Fuel Cells bergantung pada reaksi oksidasi dan reduksi dalam ruang anodik dan katodik. Dalam ruang anodic, substrat atau zat organik yang terdapat dalam limbah kulit pisang dioksidasi oleh sistem pernafasan bakteri tanpa kehadiran oksigen. Elektron melewati transpor elektron dan proton menyebrangi membran sel untuk menghasilkan adenosin triphosphate (ATP). Elektron dan proton keluar melalui rantai transpor elektron ke terminal aseptor elektron, seperti oksigen. Perbedaan potensial reduksi antara donor elektron dan aseptor elektron adalah penentu ketersediaan energi potensial mikroorganisme untuk proses anabolisme [3]. Elektron yang dihasilkan dalam MFC mengalir dari anoda melewati sirkuit listrik eksternal ke katoda menghasilkan arus listrik. Ketika elektron pindah secara eksternal, proton berdifusi dari anoda ke katoda melalui membran kation untuk menyempurnakan sirkuit internal (Gambar 2). Pada katoda, elektron dan proton bergabung untuk mereduksi terminal aseptor elektron, yaitu oksigen. Oleh karena itu bakteri dalam anoda secara fisika terpisah dari terminal aseptor elektron dalam ruang katoda. Energi listrik diproduksi oleh MFC berdasarkan kecepatan aliran elektron melewati sirkuit dan perbedaan potensial elektrokimia melewati elektroda [6].

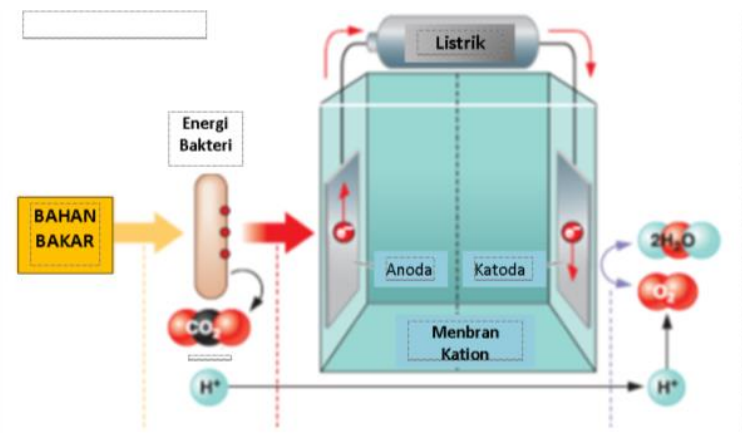

Gambar 2. Ilustrasi Skema Microbial Fuel Cells [6]

Jadi dalam penelitian ini arus listrik dihasilkan oleh mikroorganisme alami yang berada dalam limbah kulit pisang. Mikrorganisme limbah kulit pisang yang berada dalam ruang anodik akan menempel pada elektroda anoda akan mengoksidasi senyawa organik dalam limbah kulit pisang memproduksi proton dan elektron serta karbondioksida sebagai produk oksidasi. Elektron dalam ruang anodic di transfer ke katodik melewati sirkuit eksternal yang akan menghasilkan muatan eksternal listrik, dan proton di transfer melalui membran. Elektron dan proton bereaksi dalam ruang katodik mereduksi oksidant (oksigen) dan menghasilkan listrik.

Secara umum ada dua tipe MFC; sel dengan mediator dan sel tanpa mediator. Teknologi MFC secara biologi mengambil glukosa dan metanol dari limbah (substrat) dan mengubahnya menjadi hidrogen dan makanan untuk bakteri. Ketika mikroorganisme mengkonsumsi substrat seperti gula dalam kondisi aerob mikroorganisme akan menghasilkan $\mathrm{CO}_{2}$ dan air, namun ketika tanpa 
kehadiran oksigen (anaerob), mikrorganisme akan memproduksi $\mathrm{CO}_{2}$, proton dan elektron.

$\mathrm{C}_{12} \mathrm{H}_{12} \mathrm{O}_{11}+13 \mathrm{H}_{2} \mathrm{O} \rightarrow 12 \mathrm{CO}_{2}+48 \mathrm{H}^{+}+48 \mathrm{e}^{-}$

Kemudian sel menggunakan mediator anorganik untuk masuk ke rantai transpor elektron sel untuk menerima elektron yang sel produksi. Mediator melewati membran lipid sel dan dinding plasma dan mulai melepaskan elektron dari rantai transpor elektron yang secara normal akan diambil oleh oksigen dan intermediet lainnya. Ada sejumlah mediator yang disarankan untuk digunakan dalam MFC, yaitu metilen blue, thionin, natural red dan lain-lain [7]. Proses reaksi kimia dalam MFC untuk menghasilkan arus listrik dapat di lihat pada Gambar 3.

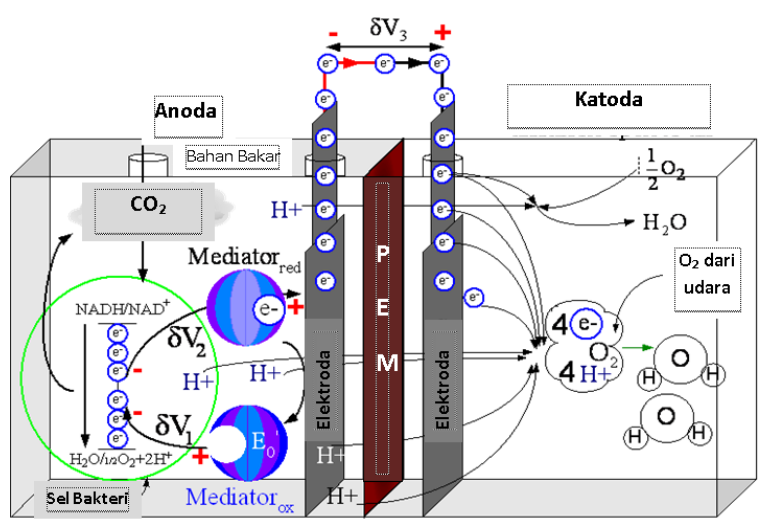

Gambar 3. Proses Reaksi Kimia dalam MFC untuk Menghasilkan Arus Listrik [7]

Penelitian ini menggunakan metoda tak langsung sehingga membutuhkan tambahan mediator elektron. Pada penelitian ini digunakan metilen blue sebagai mediator elektron. Metilen blue dipilih karena berdasarkan penelitian yang dilakukan oleh Zou YJ, Sun LX, Xu F dan Yang LN, menggunakan metilen blue sebagai mediator elektron dalam MFC dengan memanfaatkan Escherichia Coli sebagai mikroorganisme, dapat menghasilan power density maksimum 116 $\mathrm{mW} / \mathrm{m} 2$ dengan potensial $0,76 \mathrm{~V}$ dan kuat arus $1.108 \mathrm{~mA}$ [7].

Pada katodik, terdapat $\mathrm{KMnO}_{4}$ yang berguna untuk menangkap elektron (aseptor elektron) yang berasal dari anodik. Menurut Shijie You dan kawan-kawan, permanganat dapat digunakan sebagai efektif katodik aseptor elektron untuk MFC, dengan menggunakan permanganat sebagai aseptor elektron dibawah kondisi asam dapat meningkatkan power density 11 kali lipat dibandingkan menggunakan ferrycyanida dan oksigen. Reaksi yang terjadi pada katoda, dengan menggunakan $\mathrm{KMnO}_{4}$ sebagai katodik dalam lingkungan asam diberikan dibawah ini:

Katoda: $\mathrm{MnO}_{4}^{-}+4 \mathrm{H}^{+}+3 \mathrm{e} \rightarrow \mathrm{MnO}_{2}+2 \mathrm{H}_{2} \mathrm{O}\left(\mathrm{E}^{\circ}\right.$

$$
=1,7 \mathrm{~V} ; \mathrm{pH}=1 \text { ) }
$$

Proton dan elektron yang berasal dari anoda digunakan untuk mereduksi $\mathrm{Mn}^{7+}$ menjadi $\mathrm{Mn}^{4+}$. Kalium permangabat juga mengalami fotodekomposisi atau terdekomposisi jika terkena cahaya. Reaksi yang terjadi adalah sebagai berikut:

$$
2 \mathrm{KMnO}_{4} \rightarrow \mathrm{K}_{2} \mathrm{MnO}_{4}+\mathrm{MnO}_{2}+\mathrm{O}_{2}
$$

Maka pada saat penelitian dilaksanakan, bejana katoda dibuat berwarna hitam untuk menghindari fotodekomposisi.

\section{Produksi Energi Listrik}

Produksi energi listrik yang dihasilkan selama operasi MFC limbah kulit pisang diukur dengan menggunakan multimeter yang dihubungkan dengan kedua elektroda pada reaktor MFC. Anoda dihubungkan dengan kutup negatif pada multimeter dan katoda dihubungkan dengan kutup positif dengan hambatan $50 \Omega$. Perubahan arus listrik operasi MFC limbah kulit pisang selama 17 hari ditunjukkan pada Gambar 4. Kuat arus listrik pada hari pertama operasi MFC adalah $0,027 \mathrm{~mA}$. Kuat arus meningkat pada hari ke-2 menjadi $0,03 \mathrm{~mA}$ kemudian turun pada hari ke-3 menjadi 0,028 mA. Pada hari ke-4 kuat arus naik menjadi $0,0315 \mathrm{~mA}$ dan mencapai puncaknya pada hari ke-7, yaitu $0,032 \mathrm{~mA}$ dan kuat arus cendrung stabil hingga hari ke-9. Hari ke-10 kuat arus listrik turun menjadi $0,03 \mathrm{~mA}$ dan naik pada hari ke-11 menjadi 0,031 mA dan turun pada hari ke-12 menjadi 0,028 mA. Pada hari ke-14 kuat arus naik menjadi $0,03 \mathrm{~mA}$ dan cendrung turun hingga hari ke-17 menjadi 0,0285 mA.

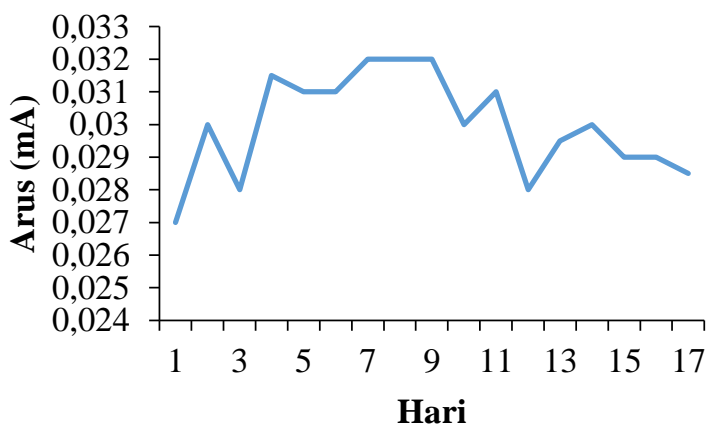

Gambar 4. Perubahan Arus Listrik Selama Operasi MFC

Gambar 5 menunjukkan perubahan tegangan listrik selama 17 hari operasi MFC limbah kulit pisang. Pada awal pengamatan tegangan listrik yang diperoleh cukup tinggi yaitu $1,195 \mathrm{~V}$. Tegangan listrik meningkat cukup tajam pada hari ke-2 menjadi 1,374 V, kemudian turun pada hari ke-3 menjadi 1, $295 \mathrm{~V}$. Pada hari ke-4 tegangan naik menjadi $1,437 \mathrm{~V}$ dan mencapai 
puncaknya pada hari ke-7 yaitu 1,455 V. Tegangan listrik kemudian turun hingga hari ke10 menjadi $1,385 \mathrm{~V}$, naik sedikit di hari ke-11 menjadi $1,403 \mathrm{~V}$ dan tegangan listrik turun teratur hingga hari ke-17 menjadi 1,365 V. Berdasarkan Gambar 4 dan 5 terlihat tegangan meningkat dengan meningkatnya arus listrik, hal ini mengindikasikan meningkatnya pelepasan electron [8].

Tegangan listrik maksimum yang diperoleh dari limbah kulit pisang dalam penelitian ini lebih besar dari penelitian yang dilakukan oleh Pranab $\mathrm{K}$ Barua, dkk, yang memperoleh tegangan listrik maksimum $147 \mathrm{mV}$ menggunakan kotoran sapi.

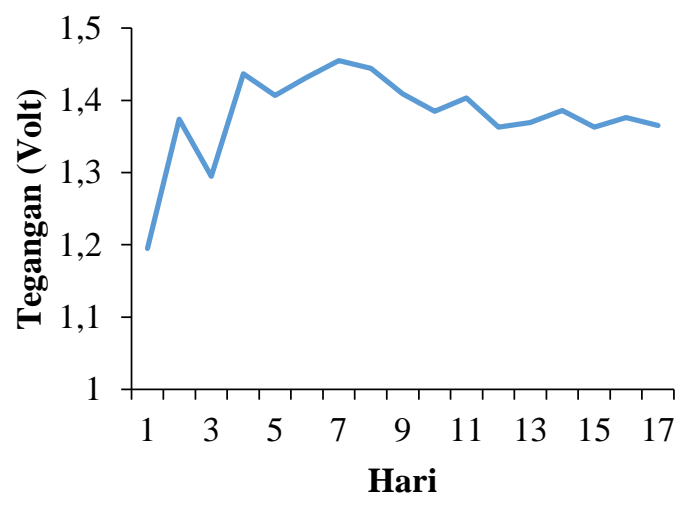

Gambar 5. Perubahan Tegangan selama operasi MFC

Gambar 6 menunjukkan perubahan power density yang diperoleh selama 17 hari operasi reaktor MFC menggunakan limbah kulit pisang. Pada awal pengamatan, power density limbah kulit pisang adalah $22,1 \mathrm{~mW} / \mathrm{m}^{2}$ dan power density mengalami penurunan pada hari ke-3 menjadi $24,8 \mathrm{~mW} / \mathrm{m}^{2}$ dan meningkat lagi pada hari ke-4 menjadi $31,0 \mathrm{~mW} / \mathrm{m}^{2}$. Hal ini disebabkan karena mikroorganisme sedang berada pada fase lag atau fase adaptasi, dimana pada fase ini mikroorganisme sedang menyesuaikan diri dengan lingkungan yang baru. Pada proses pengolahan awal, energi yang dihasilkan dari metabolisme bahan organik sebagian besar digunakan untuk membentuk biofilm. Sel-sel teradsorpsi pada permukaan media, kemudian tumbih, berkembang biak dan menghasilkan extracellular polymeric subtances (EPS) untuk membentuk biofilm. Elektroda grafit pada ruang anodic berperan menjadi media lekat pada mikroorganisme untuk membentuk biofilm. Selain sel bakteri hidup dan sel bakteri yang mati dapat membentuk lapisan pada permukaan anoda semakin bertambah. Apabila permukaan elektroda sudah dipenuhi oleh biofilm, jumlah elektron yang ditransfer ke elektroda semakin sedikit sehingga terjadi penurunan arus listrik [9].

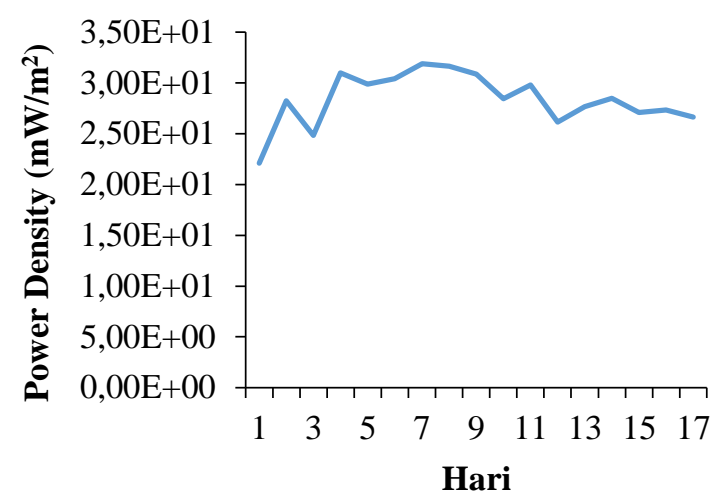

Gambar 6. Perubahan Power Density Selama Operasi $\mathrm{MFC}\left(\mathrm{mW} / \mathrm{m}^{2}\right)$

Pada pengamatan selanjutnya power density cenderung naik pada hari berikutnya hingga mencapai puncaknya pada hari ke-7 $31,9 \mathrm{~mW} / \mathrm{m}^{2}$. Hal ini menunjukkan mikroba sedang berada pada fase eksponensial. Pada fase ini, sel mikroba membelah dengan cepat dan konstan. Bertambahnya jumlah sel bakteri ini memungkinkan semakin banyaknya proton dan elektron yang dapat dihasilkan dari proses metabolisme sehingga arus listrik yang terbaca semakin besar. Pada jam berikutnya, kuat arus yang dihasilkan turun seiring dengan berkurangnya jumlah glukosa yang tersedia. Hal ini sesuai dengan kesimpulan Chaudhuri dan Lovley bahwa potensial dan kuat arus berbanding lurus dengan konsentrasi substrat yang tersedia untuk dioksidasi [10].

Besarnya power density yang dihasilkan menunjukkan bahwa limbah kulit pisang dapat digunakan sebagai substrat untuk produksi energi listrik menggunakan teknologi MFC. Hal ini didukung oleh penelitian Lisa Utami dkk, yang memperoleh power density $121,700 \mathrm{~mW} / \mathrm{m}^{2}$ dengan memanfaatkan limbah kulit buah pepaya sebagai sumber energi listrik dengan memanfaatkan teknologi MFC [4].

\section{SIMPULAN}

Berdasarkan hasil penelitian dapat disimpulkan bahwa limbah kulit pisang dapat digunakan sebagai substrat untuk produksi energi listrik menggunakan teknologi MFC dengan power density maksimum $31,9 \mathrm{~mW} / \mathrm{m}^{2}$. $\mathrm{pH}$ awal operasi MFC adalah 3,86 menunjukkan bahwa limbah memiliki $\mathrm{pH}$ yang sangat asam dan setelah 17 hari operasi MFC $\mathrm{pH}$ limbah naik menjadi 5,02 . Limbah kulit pisang tidak mampu untuk menghilangkan ion sulfat. 


\section{UCAPAN TERIMA KASIH}

Ucapan terima kasih kami berikan kepada pihak Lembaga Penelitian dan Pengabdian Kepada Masyarakat (LP2M) Universitas Islam negeri Sultan Syarif Kasim Riau yang telah memberikan bantuan dana penelitian sehingga penelitian ini terlaksana dengan baik dan juga kepada tim pembantu peneltian yang telah bekerjasama dengan solid.

\section{REFERENSI}

[1] O S Powar, "Influence of Carbon Based Electrodes On The Performance of The Microbial Fuel Cells," International Journal of Research Granthaalayah, 2017.

[2] Bose , "Electricity Generation and Other Aplication Using Microbial Fuel Cells," 2016.

[3] Du Haxia, "Potato Waste Treatment by Microbial Fuel Cell Evaluation Based on Electricity Generation Organic Matter Removal and Microbial Structure," 2017.

[4] L Utami, Lisa , and Lazulva , "Produksi Energi Listrik dari Limbah Kulit Pepaya Menggunakan Teknologi Microbial Fuel Cells," Al-Kimia, pp. 2549-9335, 2017.
[5] Momoh and Yusuf , "A Novel Electron Acceptor For Microbial Fuel Cells: Nature of Circuit Connection On Internal Resistance," Biochemichal Journal, 2016.

[6] K C Wrighton, "Microbial Fuel Cells: Plug-in and Power On Microbiology," 2009.

[7] D Pranab, B, and K Barua, "Electricity Generation From Biowaste Based Microbial Fuel Cells," International Journal Energy, vol. 1, no. 1, 2010.

[8] Y Shijie, "A Microbial Fuel Cells Using Permanganate As Cathodis Electron Acceptor," 2006.

[9] T Y G Zhuwei Du and Haoran Li, "A State of the Art Review on Microbial Fuel Cells: A Promising Technology for Wastewater Treatment and Bioenergy," Biotechnol. Adv. Elsevier, 2007.

[10] D Permana, "Evaluasi penggunaan Metilen Biru sebagai Mediator Elektron pada Microbial Fuel Cells dengan Biokatalis Acetobacter Aceti," 2013. 